\title{
Entrevista sobre voz e treinamento vocal com Carlos Simioni
}

\section{Interview on voice and vocal training with Carlos Simioni}

Entrevista com Carlos Simoni concedida à Chavannes Péclat ${ }^{1}$ 


\section{Resumo}

Nesta entrevista, realizada em 08 de junho de 2018, o ator Carlos Simioni comenta sobre diversos aspectos de seu próprio trabalho, principalmente, no que diz respeito às suas mais recentes investigações sobre a voz. Trata-se de um importante material para contribuir com as reflexões de artistas e pesquisadores que estudam o trabalho do LUME-Teatro, bem como para aqueles que focam o centro de suas pesquisas nas potências vocais do ator.

Palavras-chave: Investigação sobre a voz; potência vocal; treinamento vocal

\section{Abstract}

In this interview, held on June 8 , 2018, the actor Carlos Simioni comments on various aspects of his own work, especially about his most recent research on the voice. This is an important material to contribute with the reflections of artists and researchers study the work of LUME-Teatro and for those who focus the center of their research on the vocal potentialities of the actor.

Keywords: Research on voice; vocal potential; vocal training

E-ISSN: 2358.6958

\footnotetext{
1 Mestre em Artes da Cena pela Universidade Estadual de Campinas/UNICAMP (2017). chavannespp@hotmail.com - A transcrição da entrevista foi realizada por Chavannes Péclat e Isabela Basso Perim
} 


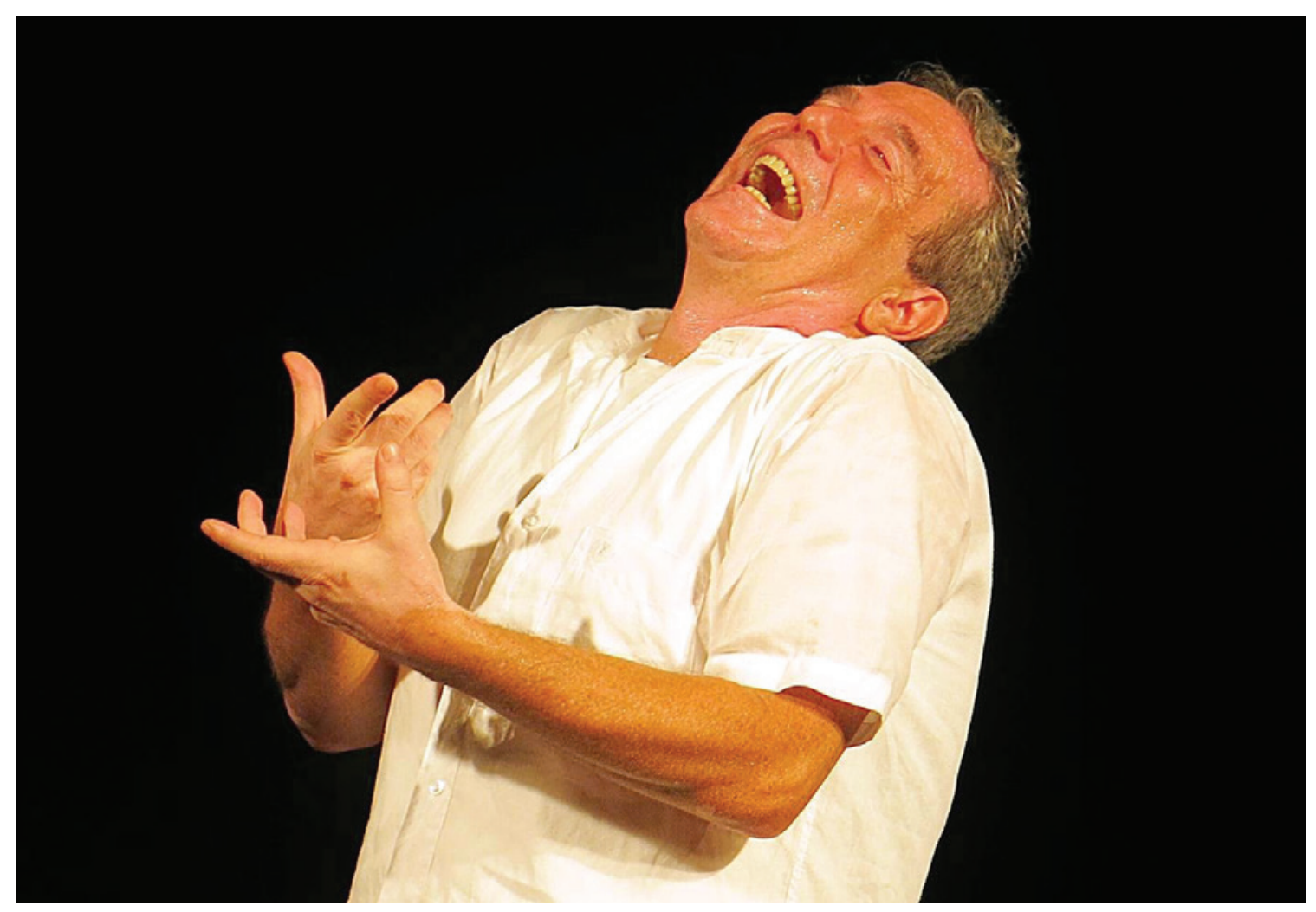

Fonte: APA - Ateliê de Pesquisa do Ator

Carlos Simioni em demonstração técnica: "Prisão para a Liberdade"2

Foto: Marta Viana

Carlos Roberto Simioni (LUME-Teatro):

Ator-pesquisador, diretor, natural de Curitiba (PR) - 20 outubro de 1958 -, radicado em Campinas (SP), foi o primeiro discípulo de Luís Otávio Burnier, com quem fundou o LUME em 1985 e desenvolveu pesquisas nas áreas da antropologia teatral e cultura brasileira; trabalhou na elaboração, codificação e sistematização de técnicas corpóreas e vocais de representação para o ator. Atualmente, além de participar dos espetáculos do LUME, ministra oficinas no Brasil e no exterior sobre treinamento corporal e vocal para o ator. É também, desde 2016, professor/ orientador no Ateliê de Pesquisa do Ator (APA) projeto de pesquisa e formação artística subsidiado pelo Centro Cultural Sesc Paraty.

Em uma entrevista ${ }^{3}$ de Renato Ferracini realizada pela pesquisadora Lissa Santi em 2011, Ferracini diz: "[a voz] é um trabalho que a gente conseguiu sistematizar muito pouco enquanto escrita". E depois comenta: "Simioni dá muitos cursos de voz e é o que mais gosta disso". Uma vez que ainda hoje existe pouco material escrito sobre o trabalho vocal do Lume e a partir da fala de Ferracini, nota-se que você é $o$ ator dentre os sete (7) que mais tem se aprofundado neste universo, poderia por favor nos contar como foram os primeiros anos da sua busca, quando foi que surgiu pela primeira vez o trabalho vocal no LUME?

\footnotetext{
2 Disponível em: http://atelieator.blogspot.com/2015/04/apa-agradece-por-prisao-para-liberdade.html. Acesso em: 08 jun. 2018

3 Santi, 2011, p.16.
} 
Primeiramente, existem dois livros sobre o meu trabalho de voz. Um produzido pela Ângela Finardi da Universidade de Santa Catarina e outro pela Moira Albornoz Stein, se quiser você consegue achar esse material. Aliás, tenho esse livro aqui se precisar. Na realidade não sei por que fui tido como o responsável pela voz, por que de fato todo o trabalho surgiu junto. Aquilo que eu falo no começo do curso ${ }^{4}$ sobre o Power Ranger... quer que eu repita a história? Não?

\section{Sim! Se puder contá-la novamente seria ótimo ter esse registro tanto para mim, quanto para quem eventualmente tiver acesso a esse material.}

Vou contar essa história inclusive para the responder como é que começou a voz. Quando começou, o LUME era apenas eu e o Luís Otávio 5 e na época eu só tinha o treinamento energético. Eram seis horas de trabalho todos os dias e geralmente fazíamos somente eu e o Luís Otavio Burnier; a metade do tempo ele parava e ficava apenas me observando e quando precisava ele entrava para me dar uma injeção de ânimo. Três, quatro, cinco meses e só isso. Às vezes ele chamava alguns alunos - não existia ainda o Departamento de Artes Cênicas - mas tinha um grupo de teatro lá na Universidade, no Instituto de Artes (UNICAMP), que ele dava aula. Às vezes ele chamava umas três, quatro ou cinco pessoas desse grupo pra fazer o energético comigo, porque com mais gente é muito melhor. E assim foi, mas a maior parte do tempo eu fazia esse treino sozinho. Eu lembro de uma das vezes em que fazíamos esse treino, não vou conseguir precisar a data, mas depois de uns seis meses, se não me engano, eu comecei a fazer o energético conforme já vínhamos trabalhando... e começou a sair sons pelo meu corpo. Sons... Gritos... sons do corpo. Não era fala, não era nada. Vozes..., mas, de fato sons do corpo, eu chamaria assim: "sons do corpo". E eu fiquei tão empolgado, porque imagine só: ficar seis meses fazendo treino energético com um cara me olhando. A impressão que eu tinha na época era que eu não crescia, não modificava. Parecia-me que era sempre a mesma coisa, apesar de também ser algo interessante porque no energético você cresce. Por mais que você ache que não, você está sempre crescendo. Crescendo no seguinte sentido: você está sempre ultrapassando os seus limites, ativando esse corpo físico e energia, esse calor e essas vibrações que aconteciam... sempre era bom, pois sempre se crescia, tinham coisas novas e etc. Mas, eu comecei a estudar esses sons e então fiquei entusiasmado e pensei: "Que bom! Agora eu não vou mais precisar fazer as mesmas coisas de sempre, pois agora eu tenho som"! Mas o som era quase como uma espécie de fuga, sabe? Tu sabes quando o som, quando a voz vem pra te dar uma muleta? Nesse sentido entende? O Burnier sempre estava muito atento as coisas que surgiam em mim, da pesquisa que ele estava realizando, sobre o que crescia, o que que aumentava, 0 que que dilatava... e o que eu conseguia ultrapassar e encontrar indo além dos meus limites. Eu fiquei muito feliz com essa voz..., mas ele falou o seguinte: "Não, Simioni. Ainda é cedo pra você soltar a voz se o teu corpo tem essa necessidade". Já que voz

\footnotetext{
4 Aqui o ator se refere ao curso de "Voz e Ação Vocal" ministrado na sede do LUME durante a programação dos "Cursos de Fevereiro" de 2018.

5 Luís Otávio Sartori Burnier Pessoa de Mello (Nascido em São Paulo - SP em 1956/Falecido em Campinas - SP no ano de 1995) Diretor, ator, mimico e performer. Foi professor do Departamento de Artes Cênicas da UNICAMP e fundador/líder do LUME-Teatro (1985).
} 
é corpo e eu não tinha nenhum trabalho de voz. "Voz é corpo. E claro, se o corpo tem necessidade de soltar esse som vamos deixar soltá-lo, mas por enquanto você segura. Você tenta fazer o treinamento energético e se essa vontade de soltar o som aparecer, você deixa agir o mecanismo vocal - que eu nem sabia o que era direito mas grite para dentro. Quando você tiver vontade de querer colocar para fora esse som, use esse mecanismo dessa vontade, mas não o deixe sair: Grite para dentro"! Essa frase: "Grite para dentro" é difícil de explicar, é quase como se a necessidade de soltar a voz tivesse um controle mental pra dizer: não solte, mas continue emitindo-o energeticamente. Certo? E foi isso, fiquei assim durante uns dez meses não soltando o som, mas gritava pra dentro. É difícil dizer o que era ficar gritando para dentro, mas é quando tu está lá fazendo seu exercício e surge aquela vontade que aciona algo no aparelho fonador, na sua garganta, cordas vocais e tudo mais... e isso é perceptível dentro do seu corpo, o envolvimento destes lugares ativos. O gritar para dentro significava acionar o mecanismo, mas sem soltar o som. Entende? Era quase como uma prisão, vamos assim dizer: "puxa, eu não posso soltar a voz, mas então eu vou soltar pra mim mesmo, lá dentro". Passados oito meses - antes nós trabalhávamos no salão da igreja aqui na Santa Isabel, onde as janelas são bem altas. Então as pessoas da rua não conseguiam ver o trabalho - o trabalho sempre foi um desnudar-se, sempre!

Eu tinha confiança plena no Burnier e o fato do energético te revelar, fazendo com que você extrapole limites, é claro que a sua pessoa, a sua alma, o ser, as tuas emoções e sentimentos vem à tona. Aliás esse era o princípio do trabalho, de fazer com que você ative o que está adormecido, o que está escondido, o que você não conhece. E isso era muito fantástico porque eu tinha essa liberdade, mostrava tudo e sabia que estava me desnudando, era surpresa até para mim as coisas que apareciam... estava seguro naquele lugar. Uma vez não pudemos trabalhar lá - na Igreja Santa Isabel - e então fomos trabalhar onde hoje é o Departamento de Dança, o DACO (UNICAMP). E em uma daquelas salas lá em cima, de noite, estava o Burnier sentado no chão da sala com algumas folhas espalhadas pelo seu redor - porque ele sempre ficava lá anotando tudo - e eu fazendo meu trabalho. Eu realmente estava entregue, desnudo e após umas duas horas estava lá... Chega um momento no energético que você já não precisa mais ficar se movimentando o tempo todo. Você entra em um fluxo, em um lugar que toda a energia parece que tem vida própria, entende? O corpo foi só um estopim, acontecia de a energia ter todo um trabalho de..., mas isso já é outro assunto. Porém eu estava desnudado, estava aflorado, estava aberto, estava puro, estava pleno. E por um momento eu passei o olho pela janela e vi o vigia me observando com um olhar muito arregalado. E na hora eu pensei: "nossa ele deve estar vendo cada coisa de mim, ele deve estar vendo todo o meu íntimo, né"? Porque era isso. E eu fiquei um pouco com vergonha... e isso não tinha um ano de LUME, não tinha ainda apresentado nada e nunca tinha mostrado nada pra ninguém. Então fiquei com vergonha até que me deu uma travada e comuniquei para o Burnier o que estava acontecendo, mas não desmanchei o trabalho. Eu falei: "puxa Burnier eu não estou conseguindo por causa do vigia". Daí o Burnier disse: "então Simioni vamos fazer o seguinte, vamos fazer um teste. Todo o grito que você gritou para dentro, agora em um grito só, você vai soltar e com o seu grito você vai expulsar o vigia". Eu lembro que 
quando ele falou isso, que ele me autorizou a soltar o som, como eu estava dilatado, como eu já estava em um estado de trabalho bem profundo, meu corpo muscular estava totalmente consciente e aguçado. Eu lembro que quando fui soltar o grito, eu dei um respiro, enchi o corpo de ar pra soltar o grito, mas antes de dar o grito, eu senti que toda a minha musculatura: tanto a do abdômen, quanto o diafragma, como o peito, como as costas, como a lombar, até o pescoço... foi se aprumando, foi se armando e é por isso que eu falo "Power Ranger", é como aquilo "Power Ranger ativar"! Mas para mim foi muito claro, muito claro! Que a voz vinha exatamente desses lugares, vinha dessa musculatura. Como eu tinha "gritado" com a musculatura para dentro de mim, é quase como se esse grito que estava latente, fixado na musculatura, ele se armou e eu pude então soltá-lo. Foi um grito que não arranhou nada e eu sentia que ele batia em todas as paredes do meu corpo e que ajudava a vibrar o som da voz e etc. Daí eu faço aquela brincadeira depois, bom... na verdade o Burnier falou que as folhas vibravam e que o vigia desapareceu. Deve ter desaparecido porque... sei lá (Risos). Porque estava só olhando um pouco talvez. Mas, justamente ali no momento em que eu peguei ele olhando... então a partir daí foi muito uma coisa de... Bom, eu contei para o Burnier como que tinha sido, e foi muito interessante, porque deu pra gente ver que a voz, para nós, era corpo. Nesse sentido do Power Ranger, ou seja, de você acionar essa musculatura. Eu não sabia o que era musculatura da voz naquela época, eu não sabia nada disso. Eu comecei e o Burnier autorizou que eu soltasse a voz em alguns momentos específicos, que eu soltasse a voz quando era justamente para se trabalhar a voz. No entanto, eu já não trabalhava mais a voz, só no sentido da voz: cordas vocais e ressonadores da cabeça. Pois todo exercício que a gente fazia de voz eu acionava essa musculatura. Porque como eu estava totalmente dilatado e perceptível - nesse momento do grito - eu tinha noção como acionar a musculatura para fazer a voz e é claro que era abdômen no meu caso. Era o abdômen... e então isso foi se desenvolvendo. E o Burnier foi ficando realmente encantado com as possibilidades de voz que saiam desse corpo, tanto é que se você pegar a tese dele, você vai ver lá nos anexos que tá tudo codificado com nomes, eu não vou me lembrar de todos agora, até porque é uma quantidade enorme de vozes diferentes. A única coisa de voz de fora que a gente tinha além desse trabalho, era uma pesquisa que o Burnier fez antes de começar o LUME lá em Quito no Equador, que ele ia até as montanhas e subia as montanhas pra soltar a voz. Não se tinha nada de Grotowski ${ }^{6}$ e eu nem conhecia a lben 7 e tudo mais. Eu me empolguei com a voz e o Burnier também, porque era fabuloso ver a tua voz saindo do corpo. Porque quase que era uma coisa só: corpo dilatado, corpo energético tinha que ter voz, porque já era, já fazia parte do treinamento, você entende? Foram surgindo diferentes ressonadores, diferentes vozes localizadas e vozes... no caso quando nós fazíamos esse energético e o Bur-

\footnotetext{
6 Jerzy Grotowski (Nascido em Rzeszów - Polônia em 1933/Falecido em Pontedera - Itália no ano de 1999) foi um influente encenador teatral do século XX, cujas ideias sobre teatro propuseram mudanças significativas na arte de ator.

Iben Nagel Rasmussen (nascida em Copenhague em 1945) é a primeira atriz a participar do Odin Teatret após a chegada do grupo em Holstebro em 1966. Além de diretora, professora e escritora é também coordenadora do grupo de pesquisa e investigação teatral Ponte dos Ventos (grupo internacional formado por artistas de diversos países do mundo). É autora do livro O Cavalo Cego, publicado no Brasil pela É Realizações (2016), livro que conta a história dos espetáculos do Odin Teatret através do cruzamento de dois olhares e de duas memórias: de um lado, está o diretor-dramaturgo Eugenio Barba (fundador do Odin em 1964) e do outro, a atriz que o interroga, Iben Rasmussen.
} 
nier estava muito interessado pelo "o acordar", o que estava adormecido. Também quando acordava vinham emoções, e era fantástico porque com esse corpo dilatado e com esse corpo já propício para fazer a voz, a voz vinha recheada de emoção, de sentimento, de vibração e de cargas... cargas do meu DNA, do meu genoma e tudo mais. Isso passou a ser um trabalho cotidiano, fazer as vozes; aliás, era bem gostoso.

Então, eu não sei por que eu acabei sendo o cara da voz do LUME ou por que as pessoas começaram a me procurar sobre a voz; eu não estava interessado pela voz, eu estava interessado pelo trabalho corporal e a voz era consequência. Realmente, eu não estava interessado, inclusive eu ficava surpreso quando as pessoas falavam do trabalho que eu tinha de voz. Mas eu realmente não percebia isso. Se dependesse de mim eu não ia focar na voz, entende?

Aconteceu de eu encontrar a Iben. E a Iben tem o trabalho de ressonadores de voz que ela aprendeu com o Grotowski - ela trabalhou com ele durante muito tempo - mas esse encontro aconteceu três anos depois em 1989, digo, quatro anos depois. Só que nós tínhamos descoberto os ressonadores sem querer fazer esse trabalho, porque a voz vibrava no estômago, vibrava aqui no peito, vibrava nas costas, vibrava em tudo quanto é lugar. Era ressonador só que a gente não tinha nomeado. Aí a Iben chega com os ressonadores, mas ela chega assim: ressonador voz normal, ressonador peito, abdômen, nariz, topo de cabeça. E isso estava junto com "o impulsionar" a voz - a alavanca que eu digo. Também é sempre muito claro que não podemos, não dá para separar o mental, o racional, porque se você quer fazer uma voz de estômago... Você tem que imaginar, teu cérebro tem que mandar a voz pra lá. Então nunca se separa. Quando eu digo trabalho de corpo, é tudo junto, o cognitivo também. O que ela [lben] ajudou para mim foi a palavra ressonador e com mais precisão direcionar as ressonâncias. Eu tive facilidade por causa de todo o trabalho que eu já tinha, eram quatro anos de LUME, já tinha até o "Kelbilim" pronto. O Kelbilim tem muitas vozes e é todo o trabalho que a gente descobriu por conta das vozes que foram codificadas e nomeadas como matrizes vocais. Bom, já respondi né? Então, só pra dizer, passei uns bons 10 anos e nunca dei curso de voz porque eu não achava... nem que eu era bom de voz. Não que hoje eu ache. Sei que eu tenho um trabalho, mas tem gente muito melhor que eu. Mas nunca me preocupei com isso, as pessoas que diziam: "Simioni, seu trabalho de voz...". Então entraram os quatro meninos: Jesser ${ }^{8}$, Raquel $^{9}, \mathrm{Cris}^{10}$ e Renato $^{11}$. E como eu estava introduzindo tudo para eles, eu achei importante passar também o trabalho vocal, que é bem diferente do que é hoje. Eu via primeiramente

\footnotetext{
8 Jesser de Souza, diretor, clown, professor e ator-pesquisador do LUME desde 1993, nasceu na cidade de Fronteira (MG). Iniciou profissionalmente seus trabalhos em teatro em 1981, em São Paulo, no Teatro-Escola Macunaíma e, posteriormente, no CPT - Centro de Pesquisa Teatral do SESC, dirigido por Antunes Filho.

9 Raquel Scotti Hirson, nascida em Brasília (DF), trabalha desde 1993 como atriz-pesquisadora do LUME, onde desenvolve pesquisas na codificação, sistematização e teatralização de técnicas corpóreas e vocais não-interpretativas do ator. É também professora no Programa de Pós-Graduação em Artes da Cena (UNICAMP).

10 Ana Cristina Colla, nasceu em São João da Boa Vista (SP) e formou-se em artes cênicas pela Universidade Estadual de Campinas (Unicamp), em 1993, quando passou a trabalhar como atriz-pesquisadora do LUME. É mestre e doutora em artes cênicas pela mesma universidade e atualmente leciona no Programa de Pós-Graduação em Artes da Cena desta instituição.

1 Renato Ferracini, Natural de Jundiaí (SP), é ator-pesquisador-colaborador do LUME desde 1993, desenvolvendo pesquisas na codificação, sistematização e teatralização de técnicas corpóreas e vocais não-interpretativas para o ator dentro de todas as linhas de trabalho do núcleo: o Treinamento Cotidiano Corpóreo e Vocal para o Ator, Clown e a Utilização Cômica do Corpo, Mímesis Corpórea, Dança Pessoal e Teatralização de Espaços Não Convencionais, além do desenvolvimento de uma metodologia didática e a sua transmissão. É autor de três livros sobre Teatro: A arte de não interpretar como poesia corpórea (2001), Café com queijo: corpos em criação (2012) e Ensaios de atuação (2013). E também leciona no Programa de Pós-Graduação em Artes da Cena (UNICAMP).
} 
que dava certo com eles, funcionava. E percebi também que tinha essa facilidade de ensinar, de transmitir. Foi por isso que eu quase que fui obrigado.

\section{Foi um chamado}

Foi um chamado, obrigado a trabalhar voz sem querer, tanto é que eu nunca gostei de dar curso de voz, mas fui dando. Até depois que o Burnier morreu, 10 anos etc., claro que quando você dá cursos, você se depara com dificuldades: como você vai conseguir transmitir aquilo que você tem? E foi nos cursos de voz que eu comecei: "eu tenho que encontrar uma maneira de passar exatamente isso, corpo". Primeiro o corpo, depois a voz. Então eu comecei com tensões. Teve um período completamente físico de tensões eu sabia que a voz também tinha uma propagação energética e vibracional, que ela era diferente da vibração do corpo físico - muscular. A vibração, eu sabia que ela emanava, então eu tentei encontrar caminhos que hoje, como você viu, estão bem mais codificados, aprimorados, mas de fazer com que através do corpo eles conscientemente soltassem a voz. Como é hoje. Só que demorou muito tempo pra eu chegar até onde eu cheguei hoje. Apesar de que esses dois livros que tem aí falam da maneira antiga. Não sei se você lembra do Thales ${ }^{12}$, que estava lá no curso, e ele disse: "Nossa Simioni, está bem diferente, tem a ver, mas está totalmente diferente do que era antes, que era bem mais corpo." Toda a coisa das camadas para ir pra fora, não sei se você lembra? Camadas que você vai para quarta, etc., eu fazia com que eles saltassem, eles saltavam e empurravam o abdômen pra fora, para a voz ir pra fora, entende? E trabalhava muito a vibração interna. Lembro que eu fiz aquela coisa de fazer a voz de dentro? Trabalhava muito isso, para quê? Depois com o corpo deles acesos, eles emitissem a vibração que eu tinha quando eu gritava mudo. Porque é isso, no fundo era uma espécie de vibração. Só que quando você solta a voz lá pra dentro, a tua musculatura vibra. Teu corpo tá acionado, ativado, com a musculatura vibrando com a voz, é como se fosse emplacar um registro ali, uma tatuagem na musculatura.

Uma vez que fica muito claro no seu trabalho que você tem total consciência, por meio das suas sensações e das suas investigações em sala de trabalho, que corpo é voz; e como você mesmo disse, foi através de várias tentativas que você buscou ativar esse corpo-voz, e que ele ficasse claro. Hoje eu percebo que você encontrou alguns códigos, como eu posso dizer... Hoje você possuí uma certa estrutura para transmitir esse corpo, essa estrutura se dá em alguns termos chaves que você coloca de maneira muito evidente seja no seu curso, na sua explicação ou no seu trabalho de demonstração prática. São eles: "Camadas", "Alavancas" e "Campo Magnético". Será que você poderia falar um pouco sobre cada termo e como eles se inserem no trabalho, como você chegou neles?

\footnotetext{
12 Thales Branche Paes de Mendonça: Artista multidisciplinar, professor e pesquisador das artes da cena. Possui graduação em Letras pela Universidade Federal do Pará (2008), mestrado (2012) e doutorado pelo Programa de Pós-Graduação em Artes Cênicas da UFBA (2017), com estágio sanduíche na Universidade de Paris - Ouest Nanterre La Défense (2015-2016). Tem experiência artística nas linguagens do teatro, da música, da dança e da performance, tendo participado de mais de 40 espetáculos, apresentando-se em espaços convencionais e não-convencionais, tais como ruas, praças, universidades e bares. Foi participante do curso de "Voz e Ação Vocal" ministrado por Simioni em 2018.
} 
Esses termos: "Camadas, Alavanca e Campo Magnético", quer dizer, eu tenho uma coisa, Chavannes, eu não me preocupo nada com conceitos e nem com os termos. Eu sei que para a Academia é muito importante, e tem que ser. Mas, como eu estou livre disso, entende? Não me interessa. Mas eles são altamente funcionais para o trabalho, certo? Então, eles podem se modificar. Por exemplo, o "Campo Magnético", antes eu chamava de "Portal". Mas a palavra portal dava muita margem para as pessoas "viajarem" em outras coisas. Eu falo campo magnético, mas poderia ser "Campo Eletromagnético", porque o teu corpo quando você aciona ele, quando você o ativa, quando você o movimenta, você está criando energia, entende? Assim como o planeta Terra também tem um Campo Eletromagnético. A Terra está o tempo todo girando, e o fato de ela ter toda uma termodinâmica, gera um calor que cria o campo magnético, certo? Nós também, 0 nosso corpo também é o mesmo, só que em uma escala micro. No meu trabalho eu também percebia que isso existia, porque energia é calor - que existia uma emanação. E comecei a me interessar muito por isso, porque quando você trabalha corpo durante muito tempo, você se sente estagnado e precisa achar outras coisas pra continuar, e apareceu esse Campo Magnético, e então eu pensei: "eu não vou trabalhar agora só com o corpo. Claro que não conseguimos criar o Campo Magnético sem o corpo físico, mas eu vou trabalhar agora isso". Bom, mas isso vem junto no momento da minha vida de trabalho que eu estava cansado de trabalhar corpo demasiadamente, cansado e desgostoso. Pensando no meu futuro, na minha velhice, eu precisava achar um outro termo e o Campo Magnético me satisfez. Então como eu posso fazer com que, pensando no "ensinador", as pessoas consigam fazer o que eu faço sem dar primazia para o corpo, mas tendo que dar primazia pro corpo que gera tudo isso. Como encontrar uma maneira de avançar. Eu precisei fazer 20 anos de energético, mas os outros não precisam porque eu descobri "tal coisa". É simplificar, crescer, evoluir. Tem uma coisa do porquê vieram as Camadas e o Campo Magnético. Inclusive eu tenho estudado mais sobre o Campo Magnético, e é por isso que hoje o chamo de "Campo Eletromagnético". Tem muito a ver.

As Camadas era porque eu sabia que pra você ativar o corpo você tem que sair do seu cotidiano. Para sair do seu cotidiano, a coisa mais simples é sair do teu eixo. Muitos anos eu fiz todo o trabalho de desequilíbrio, forma de fora do equilíbrio, do "bêbado" como a gente chamava na época, de você sair dos seus eixos. O tal do "Equilíbrio de Luxo" que o Barba fala. E ao mesmo tempo, tinha no meu trabalho inicial a hipertensão muscular, que por muitos anos era hipertensão muscular e movimento. Você tencionava os músculos e tentava... como eu faço na minha demonstração. Então eu sabia disso. Se eu tenho que sair do eixo, qual a melhor forma de fazer isso? Eu vou pra frente. Quando eu vou pra frente o máximo, até eu não poder aguentar mais, todo o meu corpo se tenciona pra me segurar. Eu comecei a fazer exercícios, aliás, movimentos, com esse corpo tencionado quando estava na "base", antes não existia as camadas, era a "Borda", você vai até a Borda, certo? Então "Borda da Frente", "Borda de Trás", e "Borda dos Lados". Não só Borda, mas movimentar as forças e as tensões do teu corpo na Borda. Fui desenvolvendo e comecei a perceber que se eu dividisse essa borda em Camadas, ou podia ser "em partes", mais tarde eu poderia trabalhar "as forças". Na primeira camada, ou na primeira parte, a minha força de tensão é bem menor que a Borda. Então, foi por uma pedagogia, para poder ensinar a emissão da voz dentro das tensões, das dosagens de tensões. Por 
isso que eu fiz as Camadas. Mas eu poderia trabalhar todo o trabalho que eu faço esquecendo as Camadas, trabalhando só a Borda. Por isso eu digo: os nomes são funcionais, eles vão vindo. Por isso que eu sei que vocês que escrevem "ficam doidos". Porque quem faz vê o que é Camada. Mas pra você escrever e conceituar Camada, é uma tarefa difícil. Então poderia ser "partes", vamos dividir o corpo em quatro partes. Mas o que foi legal de eu entrar na Borda e ter que fazer as Camadas ir e vir, que daí eu descobri também o mecanismo da criação do Campo Magnético. Se eu fico lá, com uma força que está na Quarta Camada: na Borda, e tento puxar o meu corpo com a força da Quarta Camada para a Primeira Camada, já existe em mim um Campo Magnético. Mas eu descobri como transmitir aos alunos a criação do Campo Magnético, através das forças.

Bom, a "Alavanca" vem desde a época do Burnier dentro do nosso trabalho. A Alavanca antes não tinha esse nome... e a Alavanca é um esforço maior do que você faria se estivesse trabalhando apenas com a sua musculatura cotidiana, se entende? Então se você está numa tensão de Segunda Camada e vai para uma Quarta Camada, por exemplo, você faz um esforço... logo é bem isso, a Alavanca é um esforço, e neste caso você faria um esforço quadriplicado pra mexer seu corpo. Então se você vai fazer um "lançamento", a Alavanca é inerente no corpo, porque se você vai fazer um lançamento você tem que "ativar" forças pra que dentro do teu abdômen você consiga jogar, lançar a energia. Isso é a Alavanca, entende? De você fazer um esforço de ir para fora. Não sei se você se lembra daquele momento no curso em que o $\operatorname{Elias}^{13}$ nos leu uma definição de Alavanca que ele tinha tirado do dicionário... bom, aquela definição caiu direitinho com o que estava dizendo, inclusive eu tinha ficado surpreendido, porque os termos chegam intuitivamente, assim como foi com a Alavanca, foram as Camadas e o Campo Magnético. Eu geralmente não corro atrás do significado dos termos... Eles chegam intuitivamente e são funcionais. O Campo Magnético, por exemplo, um dia eu falei em uma oficina e aquilo ficou na minha cabeça, daí um dia... Uns quatro anos depois eu estava em um avião e um físico sentou-se do meu lado e por ser uma viajem longa acabamos que conversamos. Eu comecei a perguntar sobre a física quântica e sobre campo magnético, ele me explicou direitinho e então eu pensei: "olha aí é justamente o que eu faço". Então é isso.

Durante o curso de Ação vocal, pude notar que o "texto" ou melhor a "palavra" fora a última instância que exploramos em sala de trabalho. Porque primeiro tivemos todo um momento de trabalho corporal, experimentando bem todo esse processo de Alavancas, Camadas e Campo Magnético até chegarmos na voz, no som e na emissão sonora. Depois exploramos um pouco desses sons com o gramelô e por último veio o texto. Portanto, a pergunta que lhe faço é o seguinte: tratando-se de um trabalho vocal para o ator há de fato alguma relevância maior para o som em detrimento da palavra? No caso do seu curso a palavra viria por último, devido a uma questão pedagógica e didática? Qual seria então a importância do "texto" no trabalho vocal de um ator?

\footnotetext{
Elias de Lima Lopes: Graduado em Educação Artística pela Universidade Federal da Paraíba (1993), tem especialização em Fundamentos Metodológicos da Apreciação e Crítica (UFPB-1997) e mestrado em Artes Cênicas pela Universidade Federal da Bahia (2002). É professor assistente da Universidade Federal da Paraíba. Tem experiência na área de Artes, com ênfase em Artes cênicas (Teatro: preparação do ator, encenação, orientação técnica), ensino do teatro e Butoh. Atualmente é Doutorando em Estudos Artísticos na Universidade de Coimbra - Portugal (2015). Esteve presente como ouvinte no curso de "Voz e Ação Vocal" ministrado por Simioni em 2018.
} 
Foi na verdade tudo misturado. Foi didático primeiramente, mas também eu fui... Bom, deixa eu lhe explicar o porquê. Aliás, a última coisa que eu dei no curso na verdade não foi o texto, mas a "Intenção" se lembra? Quando eu falei: "Vejam. Agora vocês têm a voz, então trabalhem a Intenção de como vocês querem atingir a outra pessoa". Então eu jogo amor... se lembra? Jogo raiva, jogo.... Já com tudo pronto, jogo com a voz preparadíssima, inclusive com o texto a Intenção. Mas isso eu ainda estou pesquisando e por isso não chegamos a fundo, porque como eu ainda não sei, resolvi trabalharmos até aí. Esta é uma coisa que ainda está sendo pesquisada, lá no APA inclusive. Então é proposital. É proposital, primeiramente, porque claro se você nasce e começa a falar você molda toda a tua língua, tua boca, o céu da boca e etc. Você pensa e você fala, certo? Então a língua está muito ligada ao pensar. Então por isso que eu falo: "O verbo. O que é o verbo"? O verbo é a maneira como você... é o encaixar das tuas emoções, das tuas intuições em verbo para você poder pensar. Se não existisse o verbo, por exemplo, você não teria como pensar. Então eu via, por exemplo... O mais engraçado é que eu não tinha consciência, para mim o fato de dar cursos me deu muita consciência do meu trabalho, porque ao mesmo tempo que eu ia ensinar, eu percebia que quando eu usava a palavra antes de ter todo um trabalho de corpo, imediatamente pelo conhecimento, pelo mecanismo de você falar de uma maneira vinda do intelecto. Por mais que você usasse o corpo, que tivesse alguns parâmetros de corpo que eu dava, na hora de se soltar a palavra, tudo isso ia por água abaixo e o que prevalecia era o "antigo". A maneira antiga de se soltar a voz. Então eu não sabia o que encaixar, eu não sabia o que eu tinha que fazer pra que eles não perdessem o trabalho já feito... eu deixava eles (os alunos) todos preparados com o corpo, daí iam soltar a voz com a palavra, perdiam tudo e voltavam para a maneira antiga. Certo? Então eu dividi exatamente assim: primeiro todo esse trabalho corporal, depois a voz para dentro, depois voz para fora somente emitindo a letra "A". Quando está formatada a "voz pura", eu percebi que o gramelô não está diretamente relacionado ao pensamento e a maneira antiga de falar. Apesar de que - por isso que eu insisto de fazermos esse processo devagar - quem fala o gramelô rápido sem esse cuidado, volta para a maneira antiga. Porque tudo o que é emissão de palavra é a maneira mais antiga, quero dizer, a maneira "normal" que nós fazemos já a vida toda. Quantos anos você tem?

\section{7}

27 anos que você faz isso, então não tem como mudar. Você entende? Ou então demora muito tempo, porque é algo muito enraizado e é o "normal". Mas nós somos atores e estamos buscando uma outra veia. O fato de ser o gramelô, eu lembro até hoje o dia em que eu descobri isso: "percebam que vocês podem continuar usando esse trabalho do corpo e da voz corporal, devagar". Você pode começar a moldar tudo de novo, a tua boca, a tua língua. Mas sem pensar nas palavras, no texto, porque também o texto tem uma coisa terrível que ele já vem com o seu significado. O significado já vem junto, acompanhado do texto. Então entra mais a cabeça. Não que a cabeça seja ruim, pelo contrário ela é superimportante, mas o texto tem esse 
aspecto. Então é isso, o trabalho se dá a ponto inclusive de você começar a moldar a tua boca, aprender a falar do mesmo jeito, só que com essa voz "nova", essa nova maneira de falar. É, de fato, como se fosse aprender uma nova maneira de falar. Certo? É lógico que no curso tudo isso passa... o curso é rápido, mas o que eu deixo são ferramentas para que o ator queira continuar, você entende? De querer continuar a se desenvolver e a se pesquisar. O fato de você começar a moldar a voz, sem precisar pensar na palavra ou no significado do texto, você vai unindo: "opa! Têm palavras, têm uma língua aqui". Então fica muito mais fácil. Digo, não que seja fácil, mas é algo muito mais simples de se fazer a conexão entre essa nova voz que saí do corpo e o moldar desta voz, desta boca e dessa língua. Para começar a articular a fala, e através das articulações começar a falar com essa nova voz. Quando tudo já está preparado, eu até brinco às vezes. Não sei se você lembra? Quando nós estávamos trabalhando com a voz que fica aqui em cima com a boca fechada, vibrando no topo da cabeça com a boca fechada, a gente abre a boca e saí toda a vibração. Você lembra disso? Que saí toda a vibração e você começa a falar e falar... Tu perdes tudo. Por causa justamente do que estava comentando, porque já é tão comum você falar sem usar da técnica corporal - vocal, que escapa tudo. Então tivemos todo o trabalho de segurar lá em cima no topo da cabeça a vibração, não soltar de uma vez o ar, para que então você comece a articular, mantendo a vibração da voz e mantendo o estado corporal - vocal. Quando você tem essa experiência, ou esse exercício, essa ferramenta, você é capaz de falar com o texto, apesar de, veja bem, quando eu dou a vocês um texto ele é sempre linear, não tem interpretação. Justamente para evitar que tenha esse jeito "antigo": texto - intelecto - maneira antiga. Para que vocês possam ir exercitando, exercitando e exercitando... sem interpretação. O que eu quero com isso? Nesse trabalho, nesse curso de voz que eu chego até aí com o texto. É justamente transmitir por completo para os atores a estrutura básica da voz, porque não adianta eu ir sair falando um texto, se eu não tiver tido enraizado bem essa nova estrutura e maneira de falar. E no caso, surpreendentemente, até comigo isto acontece; quando eu tenho um texto, quando eu falo coisas, quando eu canto, quando... nos meus trabalhos artísticos - eu tendo essa base que passo para os alunos - quando solto o texto: o verbo, automaticamente a palavra ela se encaixa junto com o trabalho corporal - vocal. Eu já não preciso mais dessa preocupação de pensar "fazer da maneira antiga não, maneira nova". Porque a voz já vem.

\section{Já navega com essa nova lógica.}

Isso mesmo, já vem com essa nova lógica. Porque também não dá para dizer "esqueça a cabeça, esqueça o intelecto", não tem como. Não é possível.

\section{Sim, não é separado.}

Não é separado. Tudo está junto. Mas o que eu faço? Eu elevo a capacidade corpórea - vocal concreta e física, e do mesmo modo que eu elevo eu vou abaixando o intelecto, eu digo "você intelecto não tem chance" e ele vai ficando humilde, ele 
vai perdendo a força... de modo que até os dois fiquem juntos. O intelecto, a razão, o texto e etc. Encontra uma ressonância no trabalho corporal e os dois caminham juntos. O que mais me preocupava sempre era o seguinte: todo o trabalho que eu assistia - às vezes tinham trabalhos artísticos sensacionais - o artista tinha um trabalho maravilhoso corporal com grande potência e etc. Mas abria a boca e aquela voz não acompanhava nada daquilo. Então essa era uma das minhas tônicas eu preciso juntar as duas coisas. E hoje, por exemplo, por meio dessa técnica... eu tenho a certeza de que os atores que trabalham comigo, e aqui não estou falando apenas de atores que fazem um curso, mas os que desenvolvem. Os que desenvolvem não têm preocupação nenhuma com o texto. O texto surge dinamicamente e ele vai com voz e corpo. E é maravilhoso, porque você pode brincar.

Parece-me que é como se nós pudéssemos desapegar daquela norma da "palavra" enquanto significado, e então pudéssemos redescobri-la, através de sua melodia escondida, não mais o seu significado, mas o som da palavra em si. A sua fala e o meu testemunho do teu trabalho me levam para esse lugar de redescoberta da voz. Inclusive pela maneira como você se coloca, quando você diz: "do antigo" ... Acredito realmente que seja uma redescoberta e reinvenção de alguns padrões culturais de condicionar a voz de determinada maneira ao longo do tempo.

Sim, porque é cotidiano. A voz está muito ligada também... veja eu não trabalho com essas coisas, mas ultimamente eu tenho lido a respeito de chacras - agora eu nunca apliquei esse tipo de abordagem e também nem sei aplicar, porque nem sei mexer isso comigo então eu não posso transmitir ou fazer com os outros - mas tenho lido que é aqui na laringe, onde está a voz... A laringe é a expressão de si mesmo. Então pensa bem, se você usa a voz no cotidiano ela se molda a aquilo que você é, dentro das tuas incapacidades, das tuas capacidades, dentro das tuas fraquezas, do que você carrega dos teus antepassados de traumas ou de outras coisas que não são traumas. Bom, porque a voz, a gente sabe disso né? Porque você vê e escuta, por exemplo, uma pessoa que tem a vozinha assim miudinha, é claro, é a vida que vai moldando. Você entende? E para nós atores, não podemos ficar apenas na nossa voz, porque nós temos quantos mil personagens pra fazer e quantas mil coisas temos para fazer? Então temos que ter uma gama imensa das possibilidades da voz. Eu estou saindo dessa coisa assim sabe... justamente de uma voz virtuosa. Na verdade, já faz tempo que eu saí dessa, mas eu entrei nessa, aliás é necessário até entrar nessa. As pessoas diziam: "poxa, olha o que esse camarada faz com a voz", mas isso porque naquele momento eu estava descobrindo e codificando coisas maravilhosas da voz. Hoje em dia eu já acho que prevalece é mais aquilo que ainda pouco eu lhe dizia, a "Intenção", o que prevalece é essa Intenção. Porque tu tiras de ti aquilo que você quer colocar para o outro. A voz é um veículo muito forte, aonde ela carrega... ela carrega você. Então se você coloca uma Intenção, qualquer que seja: ódio, raiva, amor. Essa intenção é corporal e vocal, quando você a faz com precisão, por exemplo, para esse texto eu vou jogar isso. A voz ela molda e fica uma coisa só, não fica uma voz separada, ela molda o corporal e tudo mais, e com a intenção ela "vai que é uma beleza". E às vezes não precisa fazer milhões de vozes. 
Curioso você falar dessa questão da Intenção como algo que você dá e direciona a um outro, como se pudéssemos dizer: que se doa para o outro. É curioso também porque está relacionado a minha última pergunta, que se refere inclusive a um último momento do curso. No último dia do curso lembro de estarmos todos juntos cantando uma canção, e neste instante você falou a seguinte frase: "agora meus amigos, cantem e doem esse cantar para os colegas, para o espaço, e para o outro. E vejam como é lindo isso! Nosso trabalho consiste em um ato de doação". Seria possível que você comentasse algo a respeito desse aspecto de doação do trabalho do ator e como este estaria vinculado ao seu trabalho vocal?

Veja bem, a voz... quando falo de doação, saiba que a voz está incluída dentro do trabalho corporal - vocal, lembre-se que estamos falando dessa voz que é uma coisa só com o corpo, impregnada. Nesse sentido, o trabalho de "doação" pra mim surgiu - porque é isso, eu vou crescendo, eu vou evoluindo, se você se encontrar comigo daqui cinco anos é capaz que você diga: "poxa Simioni você já chegou nisso? E quanto aquilo lá ou aquela outra coisa? Como é que era"? E é provável que eu diga: "Sim, tinha aquilo lá, mas "aquilo" me ajudou a chegar agora a isso". Então eu sou assim e graças a deus eu quero continuar sendo assim - em um momento em que eu também estava ensinando e nessa época, estava conduzindo um trabalho com os PATUANÚ14, e eu vi que eles estavam completamente poderosos. Imagine o seguinte, que eu tinha escolhido essas pessoas para eu passar a minha técnica; logo, eu estava dando tudo, e eu podia ver a minha técnica neles, o que me gratificava, porque eu sabia que tinha conseguido, que era possível transmitir para eles e que cada um poderia então seguir fazendo do seu jeito e ao mesmo tempo eu pensava: "mas eles estão poderosos demais". O que é maravilhoso para um ator, mas eu não fico até aí, entende? Então isso me deu uma coisa durante o período que estava com eles, - que eu também acredito que recebo uma intuição. Todo o trabalho que eu tenho vai juntando umas coisas nas outras que quando menos espero me dá um estalo - e também me espelhando um pouco em Kazuo Ohno e na própria Iben, porque o que mais me impressionou na Iben, além do excelente trabalho que ela já tinha, foi a sua humildade. A humildade dela enquanto pessoa e a generosidade enquanto pedagoga. Generosidade. E enquanto artista então, nem precisa falar. Comecei então a pensar, tem alguma coisa aí: ela [lben] nunca é soberba, ela nunca é cheia de si, ela nunca está acima de todos. Poxa, mas com o trabalho que ela já tem e tudo o que ela já fez etc.

Eu comecei então a me questionar, e um dia eu estava junto aos PATUANú no máximo de tudo, controlando todas as coisas: todos os estados, todas as Camadas né? - não era camadas aquela época - enfim todo o campo magnético... e me veio o seguinte pensamento: "o ator trabalha, mas ele não pode trabalhar para ele somente". É o que acontece geralmente com quase todos os artistas, que ficam naquele estado que diz: "olhem só como eu sou deus". Mas também mesmo enquanto pesquisa eu estava tentando entender o que acontece quando a gente se esvazia de tudo? Ok se esvaziar, mas sem perder o que havia construído. Como podemos esvaziar sem

14 PATUANÚ - Núcleo de Pesquisa em Dança de Ator é formado por 15 artistas do Brasil e Costa Rica. Coordenado por Carlos Simioni (Lume Teatro). 
perder? Então, foi que surgiu essa questão: "o que aconteceria com um ator que trabalha há tanto tempo - sempre me espelhando - para se chegar a esse patamar, e se lhe fosse solicitado que abrisse mão do que ele conseguiu e usasse daquilo que realmente nos serve o teatro, ou seja, "dar". E se lhe fosse pedido para "doar". Então para que eu trabalho tudo isso? No meu caso, para quê? Para ser um grande ator? Eu, modéstia à parte, desde quando comecei, todo mundo já falava: "Nossa você é um grande ator", ou seja, eu nem tinha técnica e para alguns eu já era. Ainda mais que acabei tendo a sorte de encontrar esses mestres... e então fui crescendo e crescendo... e sempre nessa de ser um ator melhor, eu fui percebendo isso e me questionando: "nossa por que a vida está me colocando nesse lugar? Dos mestres. Estou tendo a chance de poder pesquisar profundamente e etc. E se eu desistisse de tudo isso? $\mathrm{E}$ se eu não trabalhasse só para mim"? E se eu pegasse todo esse tesouro, que eu chamei "dos grandes sacrifícios do ator". Pensa bem... veja qualquer um, você também. Vamos pegar o exemplo de um ser humano que não é um artista. O sujeito constrói um império, luta pra caramba e chega um momento em que ele simplesmente decide doar tudo, todo o império, por quê? Para não ficar mais no mesmo. Porque já não há mais graça em ficar com esse império e continuar crescendo e crescendo. Bom, tinha tudo isso, o grande sacrifício do ator. Então quando estava com os PATUANÚ eu disse doem, coloquem-se em um lugar onde, ok, eu me doo. "Poxa Simi, mas isso é difícil eu trabalhei tanto para mim e agora vou ter que dar tudo isso". Sim, e este foi o exercício de doar-se. O fato de a gente doar - e veja que essa é uma atitude até psicológica - existe um querer de se esvaziar... e isso me instigava saber o que poderia acontecer. O fato de doar tudo aquilo que tem - para mim, quando aconteceu tudo isso, foi o grande elo do trabalho de ator e o grande elo do Teatro, no sentido de que estou aqui para o Teatro, para o espectador. É para eles. Claro, existem artistas que trabalham só para si mesmos e etc., mas eu não vou entrar agora nessa questão. Doar será que eu estou pronto? Será que eu como ator, nesse estilo de ator que eu sou, de me entregar ao trabalho... o que acontece? Pelo contrário, quando eu resolvi doar e que tudo saiu, algo foi para eles [espectadores]e eu fiquei ainda mais pleno. É um vazio de doar-se tudo, mas é um vazio completamente preenchido, de tal forma que é difícil de lhe explicar. Este doar-se, esvaziar-se é como a história do copo: quando o copo está cheio você não pode colocar mais nada, porque qualquer coisa que você colocar ele vai transbordar e vai derramar o que está dentro. Se está vazio, ou meio vazio, você pode colocar mais água. Esse ciclo de você se esvaziar e ir, na época já tinha o Campo Eletromagnético e tudo mais. Você se esvazia para você poder se encher um pouco mais, portanto é um ciclo.

E eu comecei a perceber que isso era necessário, inclusive era quase um complemento. Ok é isso. É até aqui. A voz a mesma coisa. Eu senti que isto era a transcendência do ator, ou seja, o ator já não quer mais nada para ele, é onde ele ganha um degrau a mais, é onde ele não está mais sozinho. Onde existe um fluxo entre eu e vocês [espectadores], existe também um fluxo que esse ato de doar, de não estar só com o ego e ser um canal, um transmissor, eleva todo o trabalho, inclusive energeticamente. Inclusive porque então não é só você. É toda uma força que eu não posso explicar, que eu não sei explicar, mas que é do universo, do próprio universo, porque se você está vivo, se você 
tem som é porque alguém criou esse corpo que é seu. Esse corpo está vivo porque ele tem um começo, ele recebe o sol e você respira e tá tudo ali, entende? Então um pouco, é para sair do individualismo do ator que diz "eu sou o máximo, olhem para minha técnica". Quando você abre isso, quando você se prontifica a doar, entra até aquilo que eu chamaria de "espiritual". Mas por espiritual, não pense em religião, não pense em deus, não pense em santo e em nada. $O$ ato da espiritualidade, de não ser só a densidade da matéria ou a densidade do pensamento, que é menos denso que a matéria. Então você entende? É algo mais, é algo... eu não sei falar. A palavra "espiritualidade", aliás eu nunca a uso, exatamente porque ela é perigosíssima. Mas quando digo espírito é você ligado ao todo: ao sol, a terra, a comida, ao ar, a ancestralidade - que está dentro dos teus genes, do DNA que você carrega. Esse corpo físico ele veio do teu pai e da tua mãe, que veio dos teus avós e por assim em diante. Porque têm um DNA, não pense que a gente nasce aqui e é um ponto zero - então foi onde eu descobri que existe algo mais além de você. Mas veja... Chavannes eu ainda tenho medo, sabia? Eu tenho receio ainda. Porque o que eu deveria fazer por exemplo: na minha demonstração ${ }^{15}$ não sei se você se lembra, na última parte, bem no final, quando fico um tempo parado diante do público. Ali naquele instante eu deveria usar a voz. Poderia até talvez, finalizar com uma canção. Mas as pessoas já choram, já ficam emocionadas, mexidas apenas com o que já é feito... então eu tenho receio, acho que eu não tenho condições de segurar o que pode acontecer com o espectador se eu soltar a voz naquele estado. Mas já estou me perguntando, porque estou com esse medo. "Tá na hora de você avançar né Simioni, está na hora de você ir além". Mas de um certo modo, quase como se estivesse fazendo uma similaridade, uma similitude, um similar, com o que faz o Workcenter ${ }^{16}$. Não conheço nada deles, mas quando eles fazem essas vozes, eu vejo que têm algo muito grande junto. Eu vejo, eu me emociono, então me toca. Mas eu tenho receio, tenho receio. Mas, vou ter que ir em frente não adianta. Na minha vida os receios, eles me frearam até um certo ponto. Quando fica o mesmo no mesmo eu vou embora e sigo.

\section{Referências}

SANTI, Lissa. Entrevista Renato Ferracini. In: Laboratório-Portal Teatro Sem Cortinas. Nov./2011, p.1-19. Disponível em: http://www.teatrosemcortinas.ia.unesp.br/Home/ poeticasdacena/entrevistas/09.pce.0003---entrevista-renato-ferracini.pdf. Acesso em: 18 jun. 2018.

Recebido em: $18 / 06 / 2018$

Aprovado em: 11/07/2018

\footnotetext{
15 Trata-se de um trabalho solo, concebido e realizado por Carlos Simioni, onde o ator aborda a própria trajetória junto do Lume e revela que a técnica pode ser tanto uma prisão quanto um trampolim para o ator. Neste espetáculo de demonstração técnica, Simioni fala sobre o seu percurso desde a fundação do Lume, em 1985, seu encontro com os mestres de teatro, as técnicas desenvolvidas junto do grupo, como o treinamento físico cotidiano, a construção de técnicas de expansão e dilatação do corpo no espaço e no tempo, técnicas de manipulação de diferentes qualidades de energias e sua distribuição no espaço, além do treinamento vocal.

16 The Workcenter of Jerzy Grotowski and Thomas Richards: fundado em 1986 por Jerzy Grotowski, o Workecenter é um laboratório e grupo de investigação performático que trabalha desde a sua fundação com cantos tradicionais e ações físicas. Atualmente a pesquisa do Workcenter tem sido conduzida por Thomas Richards (colaborador essencial de Grotowski e diretor do coletivo artístico em questão) e Mario Biagini (diretor associado). Ambos estiveram juntos com Grotowski na última fase de seu processo investigativo, conhecido por "Arte como Veículo".
} 